\title{
Ordforklaringer
}

Livmorhalskreft er den nest hyppigste årsak til kreftdødsfall hos kvinner globalt. Forekomsten og dødeligheten er høyest i utviklingsland. I Europa diagnostiseres årlig om lag 52000 pasienter med sykdommen første gang, hvorav 27000 dør av den. I Norge har et nasjonalt masseundersøkelsesprogram mot livmorhalskreft vært i drift siden 1995. Formålet er å redusere forekomst og dødelighet og samtidig fremme rasjonell prøvetaking (1).

\section{Kartlegging av kreftgenomet ved livmorhalskreft}

\author{
Kunnskap om kopitallsvariasjoners betydning for respons på behand- \\ ling kan trolig brukes til å bedre behandlingsopplegget ved livmorhals- \\ kreft.
}

Kvinner med lokalavansert livmorhalskreft er en stor pasientgruppe. Primærbehandlingen er kurativ stråleterapi. Behandlingen er utfordrende, og strålerelaterte skader på organer i bekkenet er ikke uvanlig.

Gevinsten av et individualisert opplegg der sykdommens biologiske karakteristika inkluderes er derfor stor.

Genetiske feil i form av endret antall kopier av genene forekommer ofte i kreftceller. Ved bruk av molekylære screeningmetoder har norske forskere kartlagt hele kreftgenomet til 100 pasienter med livmorhalskreft for å finne endringer i geners kopitall og deres betydning for behandlingsutfallet (1).

- Vi fant at for pasienter med tap av helt spesifikke områder på tre kromosomer var risikoen for tilbakefall økt 3-4 ganger. Disse genetiske tapene er derfor mulige markører for behandlingsresistens, sier Heidi Lyng ved Avdeling for strålingsbiologi, Institutt for kreftforskning, Oslo universitetssykehus, Radiumhospitalet.

- De genetiske tapene fører typisk til at kreftcellene blir motstandsdyktige mot stråling og får økt evne til å invadere det omkringliggende normalvevet og spre seg til andre organer. Dette er derfor sannsynlige steg i utviklingen mot aggressiv sykdom. Tilsvarende analyser har ikke vært gjort før på en såpass stor pasientgruppe med denne krefttypen, sier hun.

- I dag brukes hovedsakelig kreftsvulstens størrelse, stadium og eventuell spredning til lymfeknuter i bekkenet ved diagnosetidspunktet som indikasjon på sykdommens aggressivitet. Våre genetiske data viste sterkere korrelasjon til behandlingsutfallet enn stadium og lymfeknutestatus, uavhengig av svulstens størrelse. Det er derfor mulig at en bedre evaluering av sykdommen og planlegging av behandlingen kan oppnås ved å inkludere genetiske data sammen med de tradisjonelle kliniske variablene.

Vi undersøker nå de genetiske funnene nærmere for å klargjøre deres biologiske betydning. Vi er spesielt interessert $\mathrm{i}$ om funnene kan brukes til utvikling av målrettede terapeutika som kan gis sammen med strålebehandlingen i tillegg til eventuelt å være et diagnostisk verktøy, sier Lyng.

\section{Strålebiologi}

Heidi Lyng har arbeidet med strålebiologi i kliniske studier ved Avdeling for strålingsbiologi på Radiumhospitalet gjennom mer enn 20 år. Arbeidet i denne artikkelen er et resultat av et pågående samarbeid mellom hennes forskningsgruppe, gynekologisk seksjon ved sykehuset og statistikkmiljøet ved Universitetet i Oslo. Malin Lando arbeider med en doktorgradsstudie basert på livmorhalskreftmaterialet.

Forfattere av artikkelen er Malin Lando, Marit Holden, Linn C. Bergersen, Debbie H. Svendsrud, Trond Stokke, Kolbein Sundfør, Ingrid K. Glad, Gunnar B. Kristensen og Heidi Lyng.

\section{Erlend Hem}

erlend.hem@medisin.uio.no Tidsskriftet

\section{Litteratur}

1. Lando M, Holden M, Bergersen LC et al. Gene dosage, expression, and ontology analysis identifies driver genes in the carcinogenesis and chemoradioresistance of cervical cancer. PLoS Genet 2009; 5: e1000719
Artikkelen ble publisert i novemberutgaven 2009 av det velrenommerte tidsskriftet PLoS Genetics (www.plosgenetics.org) 